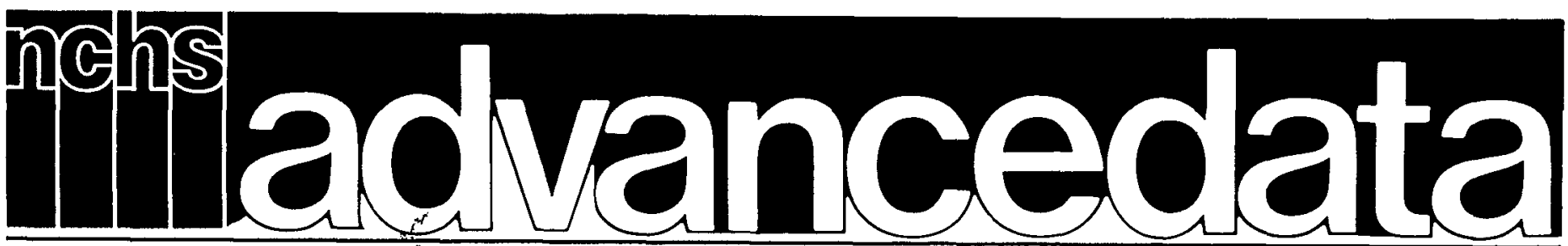

Fiom Vital and Health Statistics of the National Center for Health Statistics

Number $118 \bullet$ June 30,1986

\title{
Trends in Smoking, Alcohol Consumption, and Other Health Practices Among U.S. Adults, 1977 and 1983
}

\author{
by Charlotte A. Schoenborn, M.P.H., Division of Health Interview Statistics, and \\ Bernice H. Cohen, Ph.D., M.P.H., Johns Hopkins University
}

\section{Introduction}

The past decade has seen increasing recognition of the importance of personal health behaviors for the prevention of illness and disability. A pioneer work in this field was a study conducted in Alameda County, Calif., in the mid$1960^{\circ}$ s.' A decade later, longitudinal follow-up of the original 1965 cohort indicated that seven health habits were associated with subsequent favorable health status and reduced mortality. ${ }^{2.3}$ These habits were: never smoking, drinking fewer than five alcoholic beverages at one sitting, maintaining desirable weight for height, sleeping 7-8 hours a night, exercising, eating breakfast regularly, and avoiding snacks. In light of such evidence of the importance of personal practices for health, ${ }^{4.5}$ a national health promotion and disease prevention initiative was launched in the late 1970's. ${ }^{6}$ As an outgrowth of this initiative, broad national goals for reducing death and disability through health promotion activities were outlined, ${ }^{7,8}$ and specific quantified objectives for the year 1990 were delineated in 15 priority areas. ${ }^{9}$ Included among the prevention objectives were goals to reduce smoking and the misuse of alcohol, and to improve nutrition and physicial fitness.

In 1977, at the outset of the prevention initiative, data were collected in the National Health Interview Survey (NHIS) on the prevalence of the seven health practices found to be associated with health status and mortality in the Alameda County study. In 1983, when implementation plans were well underway, ${ }^{10}$ data on a variety of personal health practices were collected by means of the Alcohol and Health Practices survey (AHPS), a component of NHIS. With the exception of those questions concerning alcohol (discussed below), the 1977 questions were repeated in the 1983 AHPS. The availability of comparable data for 1977 and 1983 provides a unique opportunity to assess changes in behavior during a period of rapid growth in health promotion and disease prevention activities, including increases in media promotions of exercise and good eating habits and warnings of the dangers of cigarette smoking and excessive alcohol consumption.

This report presents 1983 prevalence estimates for seven health practices-hours of sleep, breakfast eating, snacking, physical activity level relative to contemporaries, smoking. alcohol consumption, and desirable body weight - for the noninstitutionalized population aged 20 years and over, by sex. race, Hispanic origin, age, income, and education. It also provides estimates of changes in the prevalence of selected unfavorable practices between 1977 and 1983. Detailed 1977 prevalence estimates for all seven practices were presented in an earlier report."

One purpose of the 1983 AHPS was to provide data to help clarify the interrelationships of health practices among U.S. adults and to further investigate their relationships to health status. Public use data tapes are available at nominal cost from the National Center for Health Statistics. Analyses of these data are encouraged.

Some sex differences were observed in the relationship between selected health behaviors and various sociodemographic characteristics. A detailed consideration of these differences is beyond the scope of this report. Tables showing sex-specific prevalence for each of the seven health practices are available on request from the Division of Health Interview Statistics.

The statistics presented and discussed in this report are simple prevalence estimates, unadjusted for age or other 
sociodemographic characteristics. Relationships between health practices and selected characteristics (education, for example) may be attributable, at least in part, to differences in the age composition of particular population subgroups. Terms such as "similar" and "the same" are used to indicate that no statistical significance exists between the statistics being compared. Terms that relate to differences (such as "greater" or "less") indicate that differences are statistically significant. The $t$-test with a critical value of $1.96(0.05$ level of significance) was used to test all comparisons that are discussed. Lack of comment regarding the difference between any two statistics does not mean that the difference was tested and found to be not significant.

\section{Sleep}

Data on sleeping practices of U.S. adults are shown in table 1. Approximately two-thirds of persons 20 years and over reported getting 7 or 8 hours of sleep on the average, and about one-fourth reported sleeping 6 hours or less a night. Black persons were more likely to be at the extremes of the sleep range than white persons. Among black respondents, 34 percent reported sleeping 6 hours or less, compared with 23 percent of white respondents; and 13 percent of black respondents reported sleeping 9 hours or more, compared with 10 percent of white respondents. People aged 45-64 appear to get the least sleep, with approximately 28 percent reporting 6 hours or less. By contrast, 21 percent of adults under 35 years of age reported sleeping 6 hours or less.

Sleeping habits also were related to income and education. Thirty percent of persons with family incomes of less than $\$ 7,000$ reported sleeping 6 hours or less, and 21 percent of persons with family incomes of $\$ 40,000$ or more reported this behavior. Similarly, 29 percent of adults with less than 12 years of education slept 6 hours or less, in contrast to 21 percent of persons with more than a high school education.

Table 1. Total population 20 years of age and over and percent distribution by average number of hours of sleep a night, according to selected characteristics: United States, 1983

\begin{tabular}{|c|c|c|c|c|c|c|}
\hline \multirow[b]{2}{*}{ Characteristic } & \multirow{2}{*}{$\begin{array}{c}\text { Population } \\
20 \text { years of } \\
\text { age and over }\end{array}$} & \multicolumn{5}{|c|}{ Hours of sleep } \\
\hline & & Total $^{2}$ & 6 or less & 7 & 8 & 9 or more \\
\hline & $\begin{array}{l}\text { Number in } \\
\text { thousands }\end{array}$ & \multicolumn{5}{|c|}{ Percent distribution } \\
\hline All persons 20 years of age and over $\ldots \ldots \ldots \ldots$ & 158,867 & 100.0 & 24.3 & 27.9 & 38.2 & 10.0 \\
\hline \multicolumn{7}{|l|}{ Sex } \\
\hline$\ldots \ldots \ldots \ldots$ & 74,600 & 100.0 & 24.9 & 29.2 & 37.2 & 8.7 \\
\hline Female $\ldots \ldots \ldots \ldots \ldots \ldots \ldots \ldots \ldots$ & 84,266 & 100.0 & 23.8 & 25.9 & 39.1 & 11.2 \\
\hline \multicolumn{7}{|l|}{ Race $^{3}$} \\
\hline 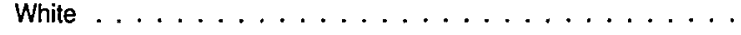 & 138,695 & 100.0 & 23.1 & 28.2 & 39.0 & 9.7 \\
\hline All other $\ldots \ldots \ldots \ldots \ldots \ldots \ldots \ldots$ & 20,172 & 100.0 & 33.0 & 22.2 & 32.8 & 12.0 \\
\hline Black . . . . . . . . . . . . . . . & 16,716 & 100.0 & 34.3 & 20.3 & 32.6 & 12.7 \\
\hline Other $\ldots \ldots \ldots \ldots \ldots \ldots \ldots \ldots$ & 3,456 & 100.0 & 26.4 & 31.3 & 33.5 & 8.9 \\
\hline \multicolumn{7}{|l|}{ Hispanic origin ${ }^{3}$} \\
\hline Hispanic . . . . . . . . . . . . . . . . & 9,596 & 100.0 & 21.2 & 24.8 & 42.0 & 12.0 \\
\hline Non-Hispanic $\ldots \ldots \ldots \ldots \ldots \ldots \ldots \ldots \ldots$ & 148,501 & 100.0 & 24.5 & 27.6 & 38.0 & 9.9 \\
\hline \multicolumn{7}{|l|}{ Age } \\
\hline $20-34$ years $\ldots \ldots \ldots \ldots \ldots \ldots \ldots \ldots \ldots$ & 59,868 & 100.0 & 20.8 & 28.2 & 40.7 & 10,3 \\
\hline 35-44 years $\ldots \ldots \ldots \ldots \ldots \ldots \ldots \ldots \ldots$ & 28,933 & 100.0 & 24.5 & 30.9 & 38.3 & 6.3 \\
\hline 45-54 years $\ldots \ldots \ldots \ldots \ldots \ldots \ldots \ldots \ldots$ & 22,169 & 100.0 & 27.5 & 29.5 & 35.7 & 7.2 \\
\hline $55-64$ years $\ldots \ldots \ldots \ldots \ldots \ldots \ldots \ldots$ & 22,004 & 100.0 & 28.0 & 27.0 & 36.5 & 8.5 \\
\hline $65-74$ years $\ldots \ldots \ldots \ldots \ldots \ldots \ldots \ldots \ldots$ & 16,377 & 100.0 & 26.5 & 22.6 & 36.7 & 14.2 \\
\hline 75 years and over $\ldots \ldots \ldots \ldots \ldots \ldots \ldots$ & 9,516 & 100.0 & 26.4 & 16.6 & 34.4 & 22.7 \\
\hline \multicolumn{7}{|l|}{ Income } \\
\hline$\ldots \ldots \ldots \ldots \ldots \ldots \ldots$ & 18,355 & 100.0 & 30.0 & 19.6 & 35.3 & 15.1 \\
\hline$\ldots \ldots \ldots \ldots \ldots \ldots \ldots$ & 29,272 & 100.0 & 25.8 & 23.7 & 38.4 & 12.1 \\
\hline 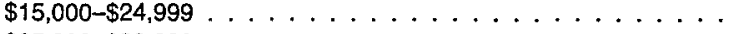 & 36,146 & 100.0 & 23.6 & 28.3 & 38.2 & 9.9 \\
\hline$\cdots \ldots \ldots \ldots$ & 36,373 & 100.0 & 22.5 & 31.8 & 38.3 & 7.4 \\
\hline$\ldots \ldots \ldots \ldots \ldots \ldots$ & 21,466 & 100.0 & 21.3 & 32.2 & 39.5 & 6.9 \\
\hline \multicolumn{7}{|l|}{ Education of individual } \\
\hline Less than 12 years $\ldots \ldots \ldots \ldots \ldots \ldots \ldots$ & 41,916 & 100.0 & 28.9 & 20.7 & 36.4 & 14.0 \\
\hline 12 years . . . . . . . . & 60,122 & 100.0 & 24.1 & 27.5 & 38.9 & 9.6 \\
\hline More than 12 years . . & 55,799 & 100.0 & 21.1 & 32.6 & 38.8 & 7.4 \\
\hline
\end{tabular}

'Includes unknowns.

2Excludes unknown hours of sleep.

${ }^{3}$ Based on self-reported identification. 
Table 2. Percent distribution of persons 20 years of age and over by frequency of eating breakfast, according to selected characteristics: United States, 1983

\begin{tabular}{|c|c|c|c|c|}
\hline \multirow[b]{2}{*}{ Characteristic } & \multicolumn{4}{|c|}{ Frequency of eating breakfast } \\
\hline & Total ${ }^{1}$ & Every day & Sometimes & Never \\
\hline & \multicolumn{4}{|c|}{ Percent distribution } \\
\hline All persons 20 years of age and over $\ldots \ldots \ldots \ldots \ldots$ & 100.0 & 53.9 & 19.0 & 27.1 \\
\hline \multicolumn{5}{|l|}{ Sex } \\
\hline Male . . . . . . . . . . . . . . & 100.0 & 52.9 & 19.3 & 27.8 \\
\hline 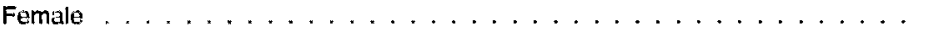 & 100.0 & 54.9 & 18.8 & 26.4 \\
\hline \multicolumn{5}{|l|}{ Race $^{2}$} \\
\hline 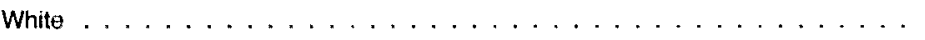 & 100.0 & 55.1 & 17.6 & 27.3 \\
\hline 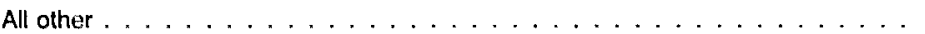 & 100.0 & 46.1 & 28.4 & 25.5 \\
\hline 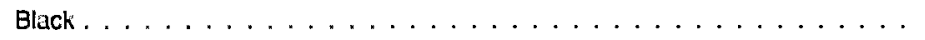 & 100.0 & 46.0 & 28.8 & 25.2 \\
\hline 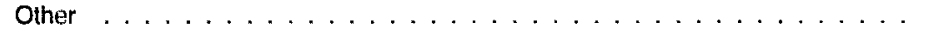 & 100.0 & 46.8 & 26.2 & 27.1 \\
\hline \multicolumn{5}{|l|}{ Hispanic origin ${ }^{2}$} \\
\hline Hispanic . . . . . . . . . . . . . . . . . . . . . & 100.0 & 53.5 & 22.8 & 23.7 \\
\hline 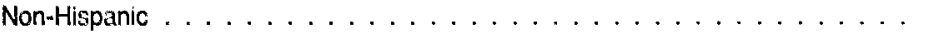 & 100.0 & 54.0 & 18.8 & 27.2 \\
\hline \multicolumn{5}{|l|}{ Age } \\
\hline 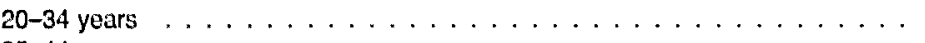 & 100.0 & 38.4 & 25.9 & 35.6 \\
\hline 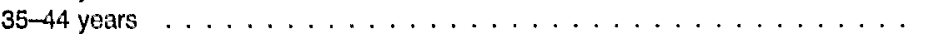 & 100.0 & 45.3 & 22.7 & 32.1 \\
\hline 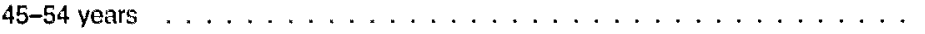 & 100.0 & 55.0 & 17.8 & 27.2 \\
\hline 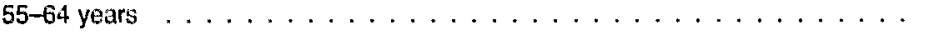 & 100.0 & 69.3 & 11.6 & 19.1 \\
\hline 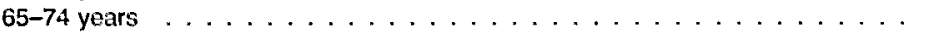 & 100.0 & 82.0 & 7.5 & 10.5 \\
\hline 75 years and over $\ldots \ldots \ldots \ldots \ldots \ldots \ldots \ldots \ldots \ldots \ldots$ & 100.0 & 91.6 & 4.0 & 4.4 \\
\hline \multicolumn{5}{|l|}{ Income } \\
\hline 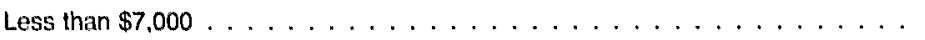 & 100.0 & 55.7 & 19.4 & 24.9 \\
\hline 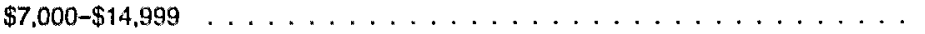 & 100.0 & 56.8 & 18.3 & 24.9 \\
\hline$\ldots \ldots \ldots \ldots \ldots$ & 100.0 & 52.8 & 19.4 & 27.8 \\
\hline 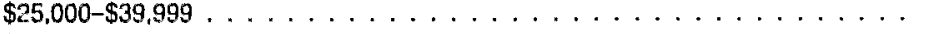 & 100.0 & 50.7 & 19.7 & 29.7 \\
\hline 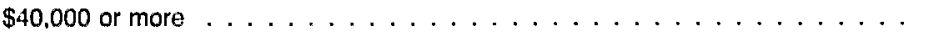 & 100.0 & 53.2 & 18.1 & 28.7 \\
\hline \multicolumn{5}{|l|}{ Education of individual } \\
\hline 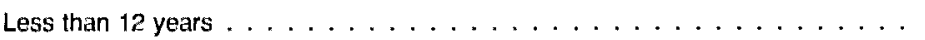 & 100.0 & 58.8 & 17.1 & 24.1 \\
\hline 12 years . . . . . . . . . . . . . . . . . . . . . . & 100.0 & 50.1 & 20.4 & 29.5 \\
\hline More than 12 years $\ldots \ldots \ldots \ldots \ldots \ldots \ldots \ldots \ldots \ldots$ & 100.0 & 54.4 & 18.9 & 26.7 \\
\hline
\end{tabular}

'Excludes unknown breakfast-eating habits.

Based on soll-reported identification.

NOTE: Sou tablo 1 for population.

\section{Eating breakfast}

Table 2 shows that more than one-half of U.S. adults eat breakfust every day, and more than one-fourth never eat breakfast. White respondents were more likely (55 percent) to eat breakfast every day than black respondents ( 46 percent). Breakfast eating habits were strongly related to age. The percent of persons who reported eating breakfast every day rose steadily from less than 40 percent of persons 20-34 years of age to more than 90 percent of persons 75 years and older.

\section{Snacking}

Datis on snacking behavior are shown in table 3. Slightly more than one-third of respondents reported snacking every day. The remaining respondents were evenly divided among those reporting snacking sometimes and those never snacking. Persons of Hispanic origin were less likely to snack every day ( 30 percent) than were non-Hispanic persons ( 38 percent). Snacking is clearly related to age, with about 40 percent of the youngest age groups reporting daily snacking, and 27 percent of the elderly, aged 75 years and over, reporting this practice. Concomitantly, only 25 percent of persons in the youngest age group indicated that they never eat snacks compared with more than 50 percent of those 75 years and over. 
Table 3. Percent distribution of persons 20 years of age and over by frequency of eating snacks, according to selected characteristics: United States, 1983

\begin{tabular}{|c|c|c|c|c|}
\hline \multirow[b]{2}{*}{ Characteristic } & \multicolumn{4}{|c|}{ Frequency of eating snacks } \\
\hline & Total ${ }^{1}$ & Every day & Sometimes & Never \\
\hline & \multicolumn{4}{|c|}{ Percent distribution } \\
\hline $\begin{array}{l}\text { All persons } 20 \text { years of age and over } \ldots \ldots \ldots \ldots \\
\qquad \text { Sex }\end{array}$ & 100.0 & 37.0 & 30.6 & 32.4 \\
\hline 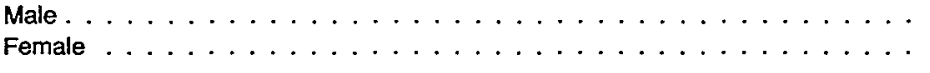 & $\begin{array}{l}100.0 \\
100.0\end{array}$ & $\begin{array}{l}38.9 \\
35.4\end{array}$ & $\begin{array}{l}28.1 \\
32.8\end{array}$ & $\begin{array}{l}33.1 \\
31.8\end{array}$ \\
\hline \multicolumn{5}{|l|}{ Race $^{2}$} \\
\hline 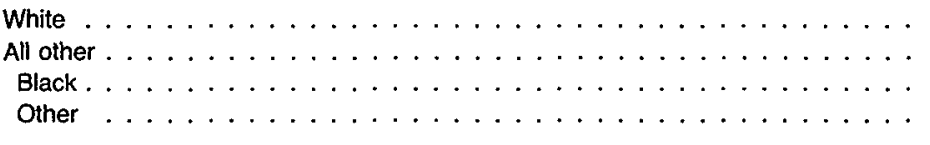 & $\begin{array}{l}100.0 \\
100.0 \\
100.0 \\
100.0\end{array}$ & $\begin{array}{l}37.4 \\
34.8 \\
35.8 \\
29.8\end{array}$ & $\begin{array}{l}29.9 \\
35.0 \\
35.0 \\
34.9\end{array}$ & $\begin{array}{l}32.7 \\
30.2 \\
29.1 \\
35.4\end{array}$ \\
\hline \multicolumn{5}{|l|}{ Hispanic origin ${ }^{2}$} \\
\hline 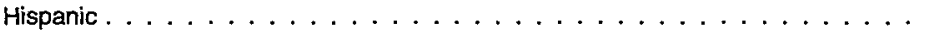 & 100.0 & 29.6 & 34.4 & 36.0 \\
\hline 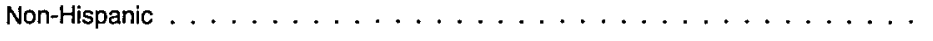 & 100.0 & 37.5 & 30.3 & 32.2 \\
\hline \multicolumn{5}{|l|}{ Age } \\
\hline 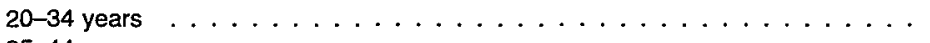 & 100.0 & 40.2 & 35.4 & 24.5 \\
\hline 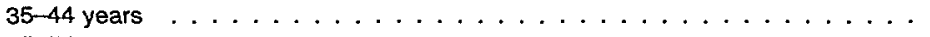 & 100.0 & 37.9 & 31.5 & 30.6 \\
\hline 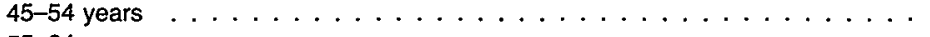 & 100.0 & 37.8 & 28.5 & 33.7 \\
\hline 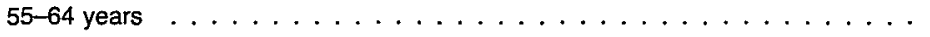 & 100.0 & 34.4 & 26.6 & 39.0 \\
\hline 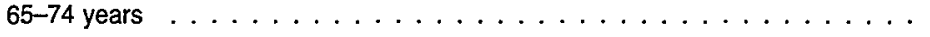 & 100.0 & 32.8 & 24.0 & 43.3 \\
\hline 75 years and over $\ldots \ldots \ldots \ldots \ldots$ & 100.0 & 26.6 & 22.8 & 50.7 \\
\hline \multicolumn{5}{|l|}{ Income } \\
\hline Less than $\$ 7,000 \ldots \ldots \ldots \ldots \ldots \ldots \ldots$ & 100.0 & 34.5 & 31.2 & 34.3 \\
\hline$\$ 7,000-\$ 14,999 \ldots \ldots \ldots \ldots \ldots \ldots$ & 100.0 & 36.7 & 30.7 & 32.7 \\
\hline 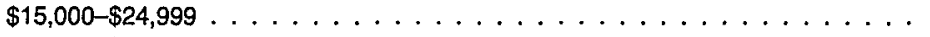 & 100.0 & 37.6 & 31.0 & 31.4 \\
\hline$\$ 25,000-\$ 39,999 \ldots \ldots \ldots \ldots \ldots \ldots$ & 100.0 & 38.5 & 31.0 & 30.5 \\
\hline$\$ 40,000$ or more $\ldots \ldots \ldots \ldots \ldots \ldots$ & 100.0 & 39.0 & 29.2 & 31.8 \\
\hline \multicolumn{5}{|l|}{ Education of individual } \\
\hline 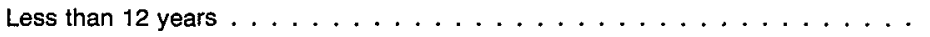 & 100.0 & 34.8 & 28.6 & 36.5 \\
\hline 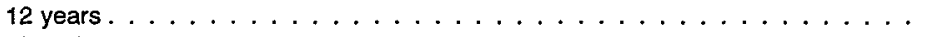 & 100.0 & 38.4 & 31.5 & 30.1 \\
\hline 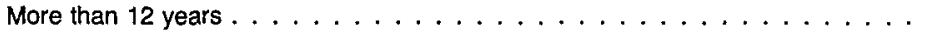 & 100.0 & 37.3 & 30.9 & 31.7 \\
\hline
\end{tabular}

'Excludes unknown snacking habits.

'Based on self-reported identification.

NOTE: See table 1 for population.

\section{Physical activity}

Table 4 shows that about 40 percent of adults considered themselves "more active" than others their own age, and 14 percent perceived their activity level to be lower than that of their contemporaries. Almost one-half of the persons in the population indicated that they were "about as active" as people the same age. Men more often reported being "more active" (44 percent) than women did ( 35 percent). Black persons more often reported being "less active" (18 percent) than white persons did (13 percent).

Perceived physical activity levels varied with age, income, and education. Thirty-six percent of persons $20-34$ years of age reported being more active in contrast to 41 percent of persons 65-74 years and 49 percent of the 75 and over age group. Interestingly, reports of being less active were also more prevalent in the older age groups; 16 percent of the oldest group, compared with 13 percent of the youngest group said they were less active. Thus, persons in the older age groups were more likely to place themselves at the extremes of the physical activity spectrum. Young people aged 20-34 years were most likely to report their activity level to be about the same as their contemporaries (52 percent), and the elderly aged 75 years and over were least likely to classify themselves this way ( 35 percent).

More active physical activity levels were associated with both income and education. Among persons with incomes of less than $\$ 7,000,33$ percent reported being more active in contrast to 46 percent of people in the highest income group. Similarly, about one-third of those persons who had not completed high school indicated that they were more active than their contemporaries, compared with 44 percent of people with post-high school education. The proportion of persons reporting themselves less active than their contemporaries declined correspondingly with both increasing income and education. 
Table 4. Percent distribution of persons 20 years of age and over by physical activity level relative to persons of same age, according to selected characteristics: Uniled States, 1983

\begin{tabular}{|c|c|c|c|c|}
\hline \multirow[b]{2}{*}{ Characteristic } & \multicolumn{4}{|c|}{ Physical activity level } \\
\hline & Tota/ & More active & Same & Less active \\
\hline & \multicolumn{4}{|c|}{ Percent distribution } \\
\hline All persons 20 years of age and over $\ldots \ldots \ldots \ldots \ldots$ & 100.0 & 38.8 & 47.4 & 13.8 \\
\hline \multicolumn{5}{|l|}{ Sex } \\
\hline 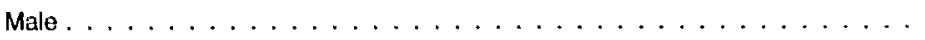 & 100.0 & 43.5 & 44.6 & 11.9 \\
\hline 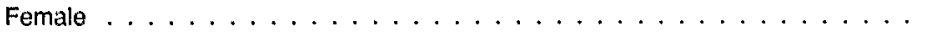 & 100.0 & 34.7 & 49.8 & 15.4 \\
\hline \multicolumn{5}{|l|}{ Race $^{2}$} \\
\hline 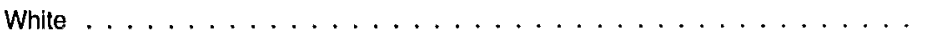 & 100.0 & 39.3 & 47.5 & 13.2 \\
\hline All other $\ldots \ldots \ldots \ldots \ldots \ldots \ldots \ldots \ldots \ldots \ldots \ldots$ & 100.0 & 35.5 & 46.9 & 17.6 \\
\hline Black . . . . . . . . . . . . . . . . . . & 100.0 & 35.5 & 46.2 & 18.3 \\
\hline 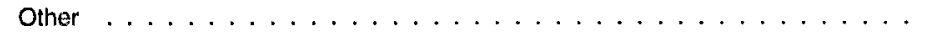 & 100.0 & 35.4 & 50.6 & 14.1 \\
\hline \multicolumn{5}{|l|}{ Hispanic origin ${ }^{2}$} \\
\hline Hispanic . . . . . . . . . . . . . . . . . . . . . . & 100.0 & 38.1 & 47.9 & 14.0 \\
\hline 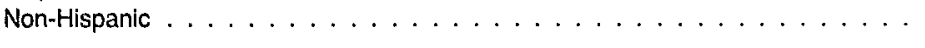 & 100.0 & 38.9 & 47.4 & 13.7 \\
\hline \multicolumn{5}{|l|}{ Age } \\
\hline 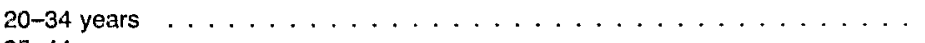 & 100.0 & 35.5 & 51.6 & 12.9 \\
\hline 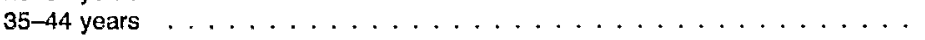 & 100.0 & 40.4 & 48.3 & 11.3 \\
\hline 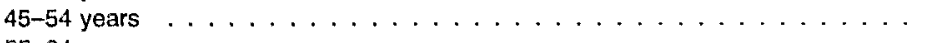 & 100.0 & 39.9 & 46.9 & 13.3 \\
\hline 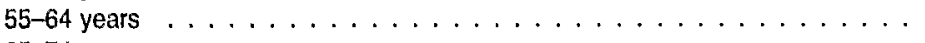 & 100.0 & 39.6 & 43.3 & 17.1 \\
\hline 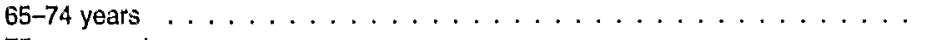 & 100.0 & 40.5 & 43.4 & 16.1 \\
\hline 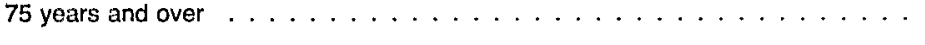 & 100.0 & 48.6 & 35.4 & 16.0 \\
\hline \multicolumn{5}{|l|}{ Income } \\
\hline 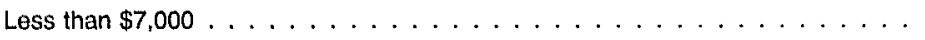 & 100.0 & 32.7 & 45.2 & 22.0 \\
\hline 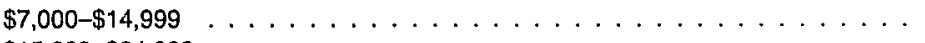 & 100.0 & 35.5 & 48.3 & 16.2 \\
\hline 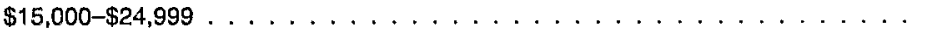 & 100.0 & 38.3 & 48.5 & 13.2 \\
\hline 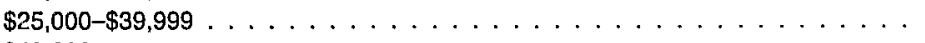 & 100.0 & 40.0 & 49.4 & 10.6 \\
\hline 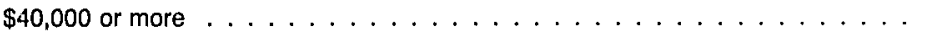 & 100.0 & 45.8 & 44.6 & 9.6 \\
\hline \multicolumn{5}{|l|}{ Education of individual } \\
\hline Less than 12 years $\ldots \ldots \ldots \ldots \ldots \ldots \ldots \ldots \ldots \ldots \ldots$ & 100.0 & 33.3 & 48.0 & 18.8 \\
\hline 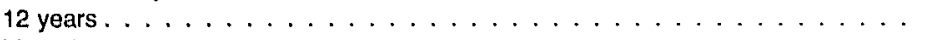 & 100.0 & 38.1 & 49.7 & 12.2 \\
\hline More than 12 years $\ldots \ldots \ldots \ldots \ldots \ldots \ldots \ldots$ & 100.0 & 43.9 & 44.5 & 11.6 \\
\hline
\end{tabular}

'Excludes unknown physical activity level.

"Based on self-reported identification.

NOTE: See table 1 for population.

\section{Alcohol consumption}

Alcohol consumption classifications shown in table 5 were developed by the National Institute on Alcohol Abuse and Alcoholism and were based on the number and frequency of drinks reported for the most recent 2-week period in which alcohol was consumed. ${ }^{12}$ Quantity and frequency of alcohol consumed was converted into average number of ounces of ethanol consumed daily, and three categories of drinkerlighter, moderate, and heavier-were derived. About one-third of respondents reported never drinking more than 12 drinks in any single year and were therefore classified as lifetime abstainers. Only 7 percent of respondents said they had been drinkers at some time in their lives but had not had a drink in the past year. These persons were classified as former drinkers. Thirty percent of AHPS respondents reported consumption patterns that were indicative of "lighter drinking," defined as between 0.01 ounces and 0.21 ounces of ethanol a day. Ten percent of the people in the population were classified as "heavier drinkers," indicating that they consumed one ounce or more of ethanol per day on the average (two or more drinks). Men and women differed markedly in their drinking habits, with 19 percent of men reporting lifetime abstention in contrast to 45 percent of women. Men were about four times more likely than women to be heavier drinkers (16 percent of men versus 4 percent of women). Among drinkers, men were twice as likely as women to have had five drinks or more on at least 1 day in the past year $(50$ percent of men compared with 23 percent of women).

Drinking habits also varied according to race and Hispanic origin. Black persons and members of other racial groups were significantly more likely to be lifetime abstainers (48 percent and 56 percent, respectively) than were white persons (31 percent). Among drinkers, black persons were less likely than white persons to report having had five drinks or more on at least 1 day in the past year ( 30 percent of black persons in contrast to 38 percent of white persons). Although Hispanic 
persons were more likely to be lifetime abstainers (46 percent) than were non-Hispanic persons (32 percent), Hispanic drinkers were more likely than non-Hispanic drinkers to have consumed five drinks or more in 1 day at some time during the past year (43 percent versus 37 percent, respectively).

Alcohol consumption was also strongly associated with age, education, and income. Younger people were more likely to drink, and they tended to drink more heavily than older people. About 26 percent of persons 20-34 years of age were lifetime abstainers, in comparison with 45 percent of persons 65-74 years and 61 percent of those 75 years and older. Among drinkers, 52 percent of the youngest group reported having had five drinks or more in 1 day, in contrast to 13 percent of adults aged $65-74$ years and only 5 percent of respondents 75 years and older. These findings are consistent with other research showing an apparent trend toward increased alcohol consumption in the younger age groups. ${ }^{13}$ Heavier drinking among young adults could indicate that young people drink more but reduce their alcohol consumption as they get older; however, lower lifetime abstention rates found for younger persons in the current analysis, combined with evidence from other studies that indicate alcohol consumption levels do not tend to decrease as people age, ${ }^{13}$ suggest that younger people are now drinking more than did earlier generations. In light of current knowledge about the harmful health and social consequences of heavy drinking, the findings of

Table 5. Percent distribution of persons 20 years of age and over by alcohol consumption, according to selected characteristics, and percent of persons who consumed 5 or more drinks in 1 day in past year: United States, 1983

\begin{tabular}{|c|c|c|c|c|c|c|c|}
\hline \multirow[b]{2}{*}{ Characteristic } & \multicolumn{6}{|c|}{ Alcohol consumption ${ }^{1}$} & \multirow{2}{*}{$\begin{array}{c}\text { Percent of } \\
\text { drinkers who } \\
\text { consumed } 5 \\
\text { or more drinks } \\
\text { in } 1 \text { day }\end{array}$} \\
\hline & Total ${ }^{2}$ & $\begin{array}{l}\text { Lifetime } \\
\text { abstainer }\end{array}$ & $\begin{array}{l}\text { Former } \\
\text { drinker }\end{array}$ & $\begin{array}{l}\text { Lighter } \\
\text { drinker }\end{array}$ & $\begin{array}{c}\text { Moderate } \\
\text { drinker }\end{array}$ & $\begin{array}{l}\text { Heavier } \\
\text { drinker }\end{array}$ & \\
\hline & & \multicolumn{6}{|c|}{ Percent distribution } \\
\hline All persons 20 years of age and over $\ldots \ldots \ldots$ & 100.0 & 33.0 & 6.7 & 29.5 & 21.0 & 9.9 & 37.7 \\
\hline \multicolumn{8}{|l|}{ Sex } \\
\hline Male $\ldots \ldots \ldots \ldots \ldots$ & 100.0 & 18.5 & 9.0 & 28.5 & 27.7 & 16.2 & 49.9 \\
\hline Female $\ldots \ldots \ldots \ldots \ldots \ldots \ldots$ & 100.0 & 45.4 & 4.6 & 30.4 & 15.1 & 4.3 & 23.4 \\
\hline \multicolumn{8}{|l|}{ Race $^{3}$} \\
\hline White . . . . . . . . . . . & 100.0 & 30.6 & 6.6 & 30.5 & 22.0 & 10.3 & 38.4 \\
\hline All other $\ldots \ldots \ldots \ldots \ldots \ldots$ & 100.0 & 49.6 & 7.2 & 22.8 & 13.8 & 6.6 & 30.9 \\
\hline Black $\ldots \ldots \ldots \ldots \ldots \ldots \ldots \ldots$ & 100.0 & 48.3 & 7.5 & 22.6 & 14.4 & 7.2 & 29.6 \\
\hline Other $\ldots \ldots \ldots \ldots \ldots \ldots \ldots \ldots$ & 100.0 & 55.8 & 6.0 & 23.8 & 10.6 & 3.9 & 37.6 \\
\hline \multicolumn{8}{|l|}{ Hispanic origin ${ }^{3}$} \\
\hline Hispanic . . . . . . . . . . . . . . . . . & 100.0 & 46.1 & 4.1 & 23.3 & 18.0 & 8.5 & 42.6 \\
\hline Non-Hispanic . . . . . . . . . . . . . . . & 100.0 & 32.1 & 6.8 & 29.9 & 21.1 & 10.0 & 37.4 \\
\hline \multicolumn{8}{|l|}{ Age } \\
\hline 20-34 years $\ldots \ldots \ldots \ldots \ldots \ldots \ldots \ldots$ & 100.0 & 26.3 & 3.5 & 33.7 & 26.1 & 10.4 & 51.8 \\
\hline $35-44$ years $\ldots \ldots \ldots \ldots \ldots \ldots$ & 100.0 & 28.2 & 6.3 & 31.9 & 23.1 & 10.4 & 36.0 \\
\hline $45-54$ years $\ldots \ldots \ldots \ldots \ldots \ldots \ldots$ & 100.0 & 32.8 & 8.1 & 28.7 & 19.1 & 11.3 & 30.2 \\
\hline $55-64$ years $\ldots \ldots \ldots \ldots \ldots \ldots \ldots$ & 100.0 & 36.3 & 9.4 & 27.3 & 17.3 & 9.8 & 21.2 \\
\hline $65-74$ years $\ldots \ldots \ldots \ldots \ldots \ldots \ldots$ & 100.0 & 45.3 & 12.2 & 22.8 & 11.7 & 8.0 & 13.2 \\
\hline 75 years and over $\ldots \ldots \ldots \ldots \ldots$ & 100.0 & 61.1 & 8.9 & 14.5 & 10.9 & 4.7 & 5.0 \\
\hline \multicolumn{8}{|l|}{ Income } \\
\hline Less than $\$ 7,000 \ldots \ldots \ldots \ldots \ldots \ldots \ldots$ & 100.0 & 47.6 & 9.4 & 20.1 & 15.2 & 7.7 & 42.5 \\
\hline$\$ 7,000-\$ 14,999 \ldots \ldots \ldots \ldots \ldots \ldots \ldots$ & 100.0 & 38.8 & 9.0 & 25.6 & 18.3 & 8.3 & 40.4 \\
\hline$\$ 15,000-\$ 24,999 \ldots \ldots \ldots \ldots \ldots \ldots . \ldots \ldots$ & 100.0 & 32.6 & 7.0 & 29.8 & 21.1 & 9.5 & 39.9 \\
\hline$\$ 25,000-\$ 39,999 \ldots \ldots \ldots \ldots \ldots \ldots$ & 100.0 & 25.3 & 5.2 & 34.8 & 23.6 & 11.0 & 37.3 \\
\hline$\$ 40,000$ or more $\ldots \ldots \ldots \ldots \ldots \ldots$ & 100.0 & 18.3 & 3.3 & 35.9 & 28.5 & 14.0 & 36.3 \\
\hline \multicolumn{8}{|l|}{ Education of individual } \\
\hline Less than 12 years $\ldots \ldots \ldots \ldots \ldots \ldots$ & 100.0 & 47.3 & 10.9 & 21.0 & 13.1 & 7.8 & 35.3 \\
\hline 12 years $\ldots \ldots \ldots \ldots \ldots \ldots \ldots \ldots$ & 100.0 & 32.1 & 6.1 & 31.8 & 20.6 & 9.5 & 38.0 \\
\hline More than 12 years $\ldots \ldots \ldots \ldots \ldots$ & 100.0 & 23.0 & 4.1 & 33.6 & 27.4 & 11.9 & 38.5 \\
\hline
\end{tabular}


more prevalent and heavier alcohol consumption among the young should be a matter of considerable public health concern.

Drinking was also associated with education, with adults in the higher educational attainment groups being more likely to drink and to drink more heavily. The relationship between drinking and income was somewhat different. Persons at the lower income levels were less likely to drink than persons with higher incomes (48 percent of persons with incomes under $\$ 7,000$ were abstainers compared with 18 percent of persons with incomes of $\$ 40,000$ or more). They were also less likely to drink heavily on a regular basis ( 8 percent of the lowest income group, compared with 14 percent of the highest income group, being classified as heavier drinkers). However, the lowest income group was somewhat more likely to have had five drinks or more on at least 1 day in the past year (43 percent) than persons in the $\$ 40,000$ or more income category were ( 36 percent).

\section{Smoking}

Data on smoking status and number of cigarettes smoked are shown in table 6. In 1983, about 32 percent of U.S. adults currently smoked cigarettes, 45 percent had never smoked, and 23 percent had smoked but quit. A larger proportion of men ( 36 percent) currently smoked than women (29 percent). Men were more likely than women to have ever smoked cigarettes (65 percent of men had ever smoked compared to 46 percent of women), but they were also more likely than women to be former smokers. About 30 percent of all men were classified as former smokers (45 percent

Table 6. Percent distribution of persons 20 years of age and over by smoking status and percent distribution of current smokers by number of cigarettes smoked daily, according to selected characteristics: United States, 1983

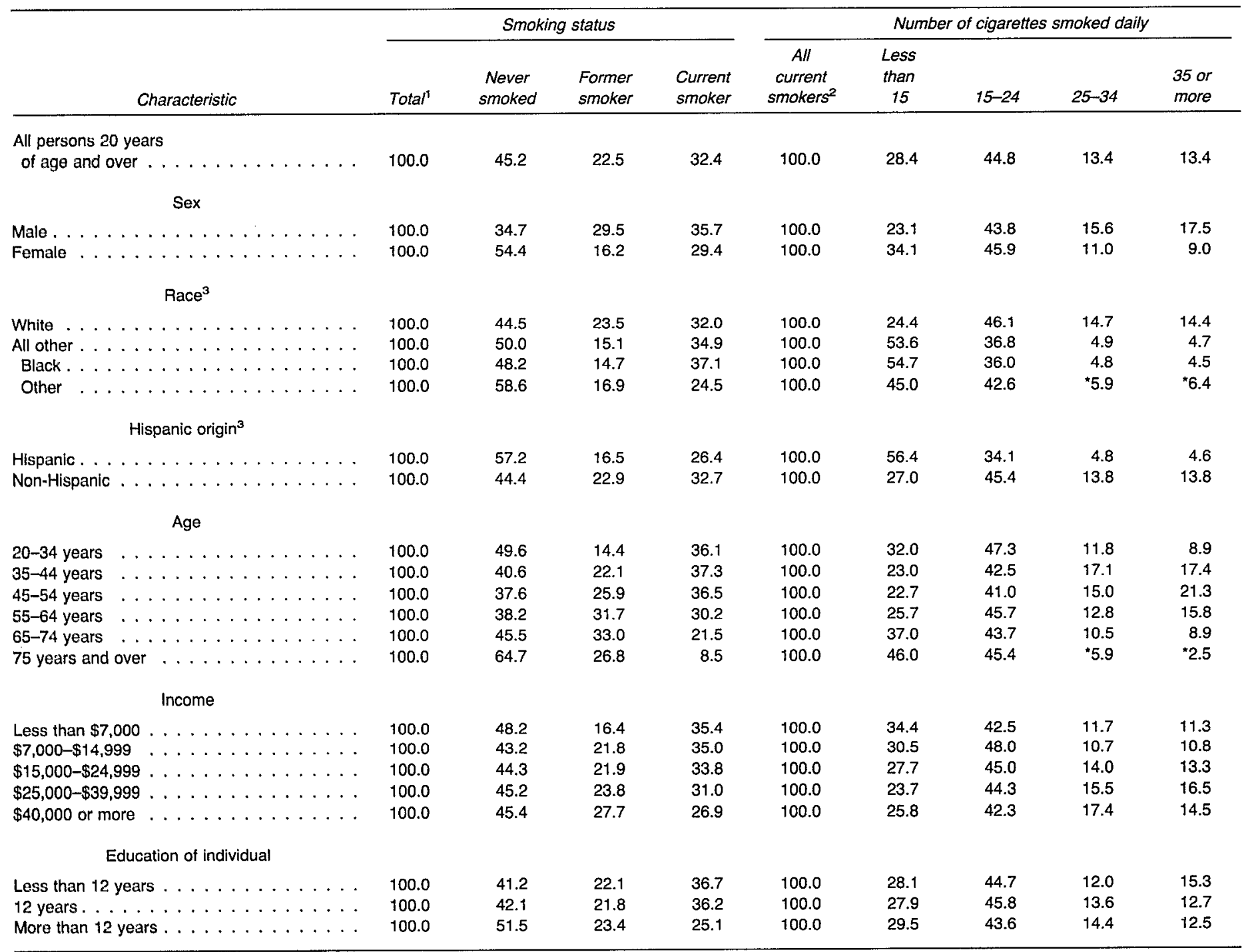

'Excludes unknown smoking status.

'Excludes unknown amount smoked.

'Based on sell-reported identification.

NOTE: See table 1 for population. 
of men who had ever smoked) compared with 16 percent of all women ( 36 percent of women who had ever smoked). Among current smokers, women appeared to smoke fewer cigarettes than men. Thirty-four percent of women smoked less than 15 cigarettes a day compared with 23 percent of men, and 18 percent of men smoked 35 cigarettes or more in contrast to 9 percent of women.

Smoking practices differed for black and white persons and for Hispanic and non-Hispanic persons. A higher proportion of black persons ( 37 percent) currently smoked cigarettes than white persons did ( 32 percent), but black smokers reported smoking fewer cigarettes per day than white smokers didabout one-fourth of white smokers (24 percent) smoked less than 15 cigarettes daily, and over one-half of black smokers (55 percent) smoked this amount. A smaller proportion of Hispanic persons reported currently smoking cigarettes (26 percent) than non-Hispanic respondents did (33 percent). Among smokers, Hispanic persons were twice as likely (56 percent) as non-Hispanic persons (27 percent) to smoke less than 15 cigarettes per day. (See Technical notes for further discussion of Hispanic smoking practices.)

Smoking practices were also related to age. Prevalence of cigarette smoking was fairly similar in all age groups under age 55, but smoking prevalence in the older age groups was sharply lower. Among persons aged 55-74, this lower prevalence of current smoking was associated with much larger proportions of former smokers; approximately one-third of persons in this age group were former smokers. In contrast, the low smoking prevalence in the oldest group ( 9 percent) is attributable to the fact that they never started smoking ( 65 percent).

Smoking prevalence was associated with education and to some extent with income. Persons with more than 12 years of education were the least likely to smoke ( 25 percent) and the most likely to have never started (52 percent) of any education group. Smoking was inversely related to income level, declining from 35 percent of persons with incomes of less than $\$ 7,000$ to 27 percent of persons with incomes of $\$ 40,000$ a year or more.

\section{Desirable weight}

Desirable weight is presented using the 1960 Metropolitan Life Insurance Company (MLIC) standards of desirable body weight for height. ${ }^{14}$ The MLIC desirable weight standards are based on the mortality experience of a group of life insurance policy holders. Because persons who obtain life insurance are not representative of the general population, the appropriateness of these standards for some population subgroups is unknown. ${ }^{15}$ The 1960 MLIC standards are slightly lower than the more recent MLIC standards, published in 1983. Thus, data presented in this report somewhat overestimate the proportion of the population that is overweight according to 1983 standards. Both MLIC and NHIS data are based on self-reported height and weight (see Technical notes for a discussion of adjustments made for reporting differences). Self-reported height and weight data produce conservative estimates of the extent of overweight in the population because heavier people tend to report lighter body weights than are obtained by actual physical measurements. ${ }^{16}$

A variety of measures of overweight status are used both within NCHS and by outside researchers. ${ }^{15} \mathrm{~A}$ major source of data on the prevalence of overweight in the U.S. population is the Second National Health and Nutrition Examination Survey (NHANES II). Data released from the NHANES II on overweight status are computed using measured height and weight and are expressed in terms of body mass index (BMI). calculated as weight divided by height squared. Although not identical, the proportions of the population defined as " 20 percent or more overweighi" using the BMI NHANES II cut-off points and the 1960 and 1983 MLIC standards are not substantially different. ${ }^{15}$ The 1960 MLIC standards were selected for the present analysis to maintain comparability with measures of overweight used in previously published research. ${ }^{11}$

Overall, about 23 percent of U.S. adults reported height and weight measurements that placed them within 5 percent of their desirable body weight, whereas 16 percent of the population was 30 percent or more above desirable weight (see table 7). The proportion of Hispanic persons and non-Hispanic persons reporting desirable weight did not differ significantly. Young people were more likely to be of desirable weight than were older people. Almost 28 percent of persons in the youngest group were within 5 percent of desirable weight in contrast to 23 percent of persons 35-44 yeurs of age and even lower proportions in the older age groups.

Women were more likely than men to be at the extremes of the desirable weight range. Twelve percent of women in contrast to 5 percent of men were in the most underweight category, and 18 percent of women compared with 13 percent of men were in the most overweight category. The proportion of persons 30 percent or more overweight differed significuntly for black and white persons. About 26 percent of black persons reported weights in this range compared with 15 percent of white persons.

Extreme overweight was also associated with both income and education. People in the lowest income and educution groups were about twice as likely to be 30 percent or more overweight compared with people at the high ends of the income and education ranges. 
Table 7. Percent distribution of persons 20 years of age and over by body weight, according to selected characteristics: United States, 1983

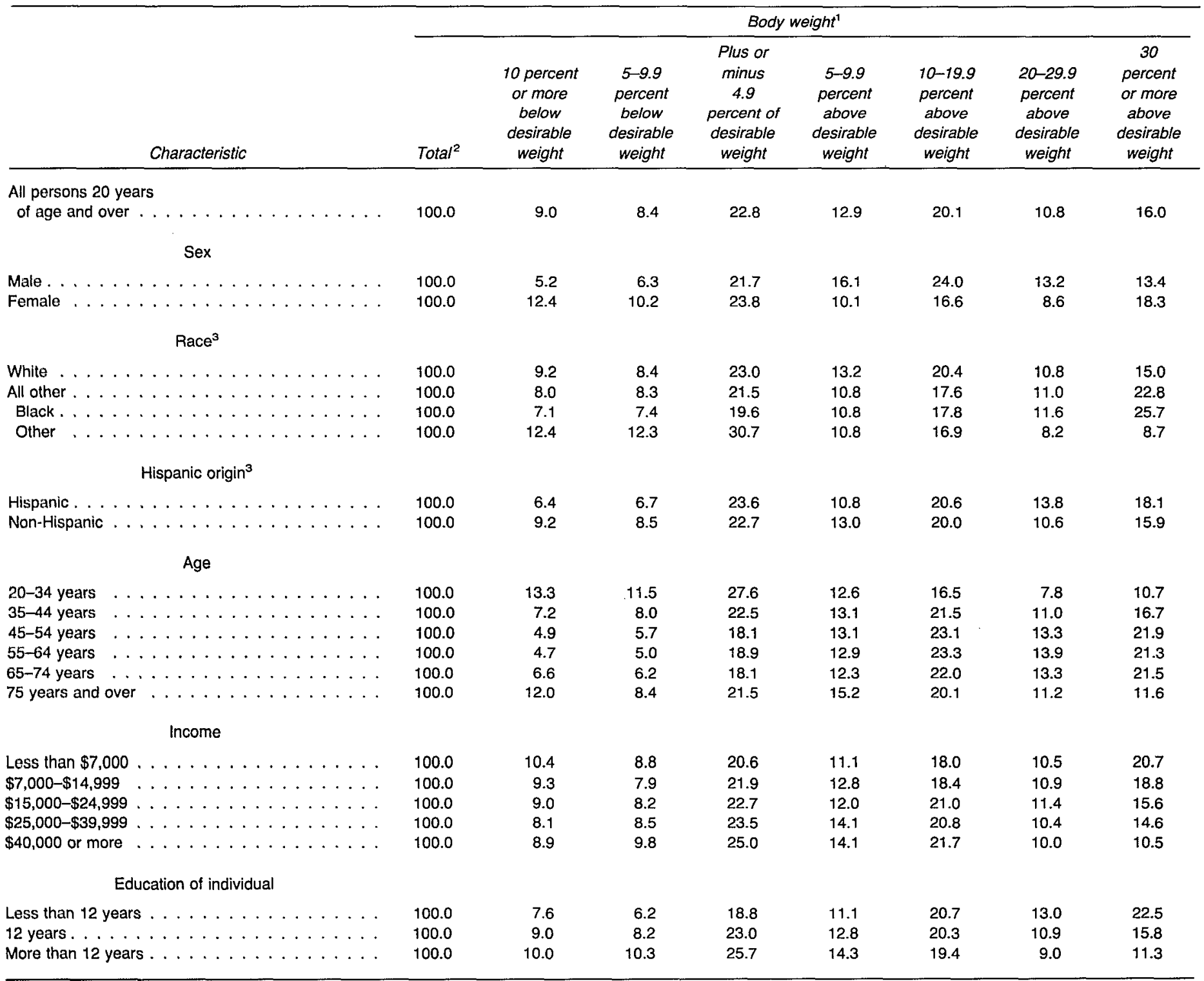

'Desirable weight baseo on 1960 Metropolitan Life Insurance Company standards. NHIS data are self-reported, and estimates may vary from those that would be obtained if physical measurements were taken.

Excludes unknown height or weight.

${ }^{3}$ Based an self-reported identification.

NOTE: See table 1 for population.

\section{Trends}

Table 8 shows changes between 1977 and 1983 in the proportion of persons reporting selected unfavorable health practices, expressed as a ratio of the proportion reporting a particular practice in 1983 to the proportion reporting the same practice in 1977 . Thus, ratios greater than 1.00 represent increases in the prevalence of the (unfavorable) practice over the 6-year period, and ratios of less than 1.00 represent decreases.

In general, between 1977 and 1983 there appears to have been an increase in unfavorable health practices, except for a decline of approximately 10 percent in reported rates of current smoking and a slight decrease in rates of irregular eating habits represented by snacking ( 3 percent). Although most of the differences were not marked, there was an increase of 10 percent or more in the prevalence rates of 4 of the
7 unfavorable practices-sleeping 6 hours or less ( 12 percent); being less physically active than contemporaries ( 12 percent); weighing 30 percent or more above desirable weight ( 10 percent); and drinking five or more drinks in any 1 day (28 percent). The proportion of persons who never eat breakfast increased only slightly (4 percent).

Declines in smoking prevalence between 1977 and 1983 signify a public health accomplishment and demonstrate that progress in being made toward reaching the 1990 objective of reducing smoking prevalence in the U.S. population to below 25 percent.

It should be noted that increases in the proportion of persons who reported that they are less physically active than their contemporaries could be attributed as much to changing perceptions of the norms of physical activity as to changes in individual physical activity levels. In both 1977 and 1983, 
the physical activity questions required that people assess their level of activity relative to others the same age, thereby measuring their perceptions of relative activity rather than any objective, quantifiable activity level. These perceptions, by definition, incorporate both an evaluation of individuals' own physical activity levels and those of their contemporaries. With recent increased publicity encouraging exercise and physical fitness, U.S. adults may perceive higher activity levels in the general population than in earlier years, even though their own physical activity levels may have remained constant or even increased slightly.
The substantial increase in the proportion of persons who reported drinking five or more drinks is difficult to interpret because of differences in question wording and context between the two survey years. In 1977, respondents were asked if they had had five or more drinks at one sitting in the past year, whereas in 1983 people were asked about having five or more drinks in any 1 day. Also, unlike the 1977 question, the 1983 question on consuming five or more drinks followed one that asked respondents whether they had had nine or more drinks in any 1 day. These and other changes in the 1983 alcohol questions allow better estimates of the alcohol

Table 8. Changes between 1977 and 1983 in the proportion of U.S. adults ages 20 years and over, reporting selected health practices: Ratio of the proportion reporting the practice in 1983 to the proportion reporting the practice in 1977

\begin{tabular}{|c|c|c|c|c|c|c|c|}
\hline \multirow[b]{2}{*}{ Characteristic } & \multicolumn{7}{|c|}{ Health practices } \\
\hline & $\begin{array}{l}\text { Sleeps } 6 \text { hours } \\
\text { or less }\end{array}$ & $\begin{array}{c}\text { Never eats } \\
\text { breakfast }\end{array}$ & $\begin{array}{l}\text { Snacks } \\
\text { every day }\end{array}$ & $\begin{array}{c}\text { Less } \\
\text { physically } \\
\text { active than } \\
\text { contemporaries }\end{array}$ & $\begin{array}{c}\text { Had } 5 \text { or more } \\
\text { drinks on any } \\
1 \text { day }\end{array}$ & $\begin{array}{l}\text { Current } \\
\text { smoker }\end{array}$ & $\begin{array}{l}30 \text { percent or } \\
\text { more above } \\
\text { desirable } \\
\text { weight }\end{array}$ \\
\hline & \multicolumn{7}{|c|}{$\begin{array}{l}\text { Ratio of the proportion reporting practice in } 1983 \\
\text { to the proportion reporting practice in } 1977\end{array}$} \\
\hline All persons 20 years of age and over $\ldots \ldots \ldots$ & 1.12 & 1.04 & 0.97 & 1.12 & 1.28 & 0.90 & 1.10 \\
\hline \multicolumn{8}{|l|}{ Sex } \\
\hline 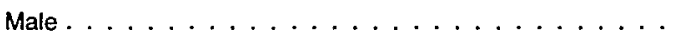 & 1.07 & 1.03 & 0.97 & 1.02 & 1.15 & 0.87 & 1.15 \\
\hline Female $\ldots \ldots \ldots \ldots \ldots \ldots$ & 1.17 & 1.04 & 0.98 & 1.21 & 1.26 & 0.92 & 1.10 \\
\hline \multicolumn{8}{|l|}{ Race $^{3}$} \\
\hline 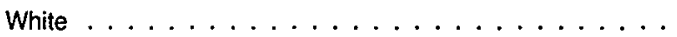 & 1.10 & 1.05 & 0.98 & 1.11 & 1.28 & 0.90 & 1.12 \\
\hline 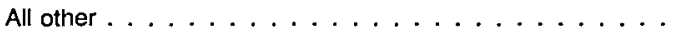 & 1.21 & 0.96 & 0.93 & 1.15 & 1.21 & 0.86 & 0.99 \\
\hline 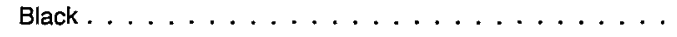 & 1.23 & 0.91 & 0.96 & 1.16 & 1.12 & 0.88 & 1.04 \\
\hline Other $\ldots \ldots \ldots \ldots \ldots$ & 1.17 & 1.33 & 0.81 & 1.24 & 2.08 & 0.84 & 0.77 \\
\hline \multicolumn{8}{|l|}{ Hispanic origin ${ }^{3}$} \\
\hline Hispanic . . . . . . . . . . . . & 0.87 & 1.10 & 0.87 & 0.92 & 1.33 & 0.79 & 0.96 \\
\hline Non-Hispanic . . . . . . . . . . . . . & 1.14 & 1.03 & 0.98 & 1.14 & 1.26 & 0.90 & 1.12 \\
\hline \multicolumn{8}{|l|}{ Age } \\
\hline 20-34 years $\ldots \ldots \ldots \ldots \ldots \ldots \ldots \ldots$ & 1.03 & 0.99 & 0.93 & 1.29 & 1.20 & 0.90 & 1.07 \\
\hline $35-44$ years $\ldots \ldots \ldots \ldots \ldots \ldots$ & 1.12 & 0.99 & 0.94 & 1.11 & 1.07 & 0.86 & 1.11 \\
\hline $45-54$ years $\ldots \ldots \ldots \ldots \ldots \ldots$ & 1.20 & 1.12 & 1.03 & 1.11 & 1.13 & 0.92 & 1.25 \\
\hline $55-64$ years $\ldots \ldots \ldots \ldots \ldots \ldots$ & 1.23 & 1.10 & 0.99 & 1.00 & 1.15 & 0.88 & 1.09 \\
\hline $65-74$ years $\ldots \ldots \ldots \ldots \ldots \ldots$ & 1.16 & 1.13 & 1.12 & 1.10 & 1.42 & 1.00 & 1.14 \\
\hline 75 years and over $\ldots \ldots \ldots \ldots$ & 1.18 & 0.77 & 1.00 & 1.00 & 1.39 & 0.85 & 0.97 \\
\hline \multicolumn{8}{|l|}{ Income ${ }^{4}$} \\
\hline Less than $\$ 7,000 \ldots \ldots \ldots \ldots \ldots$ & 1.11 & 1.23 & 1.02 & 1.02 & 2.08 & 1.06 & 1.08 \\
\hline$\$ 7,000-\$ 14,999 \ldots \ldots \ldots \ldots \ldots$ & 1.21 & 0.99 & 0.99 & 1.08 & 1.54 & 0.93 & 1.14 \\
\hline$\$ 15,000-\$ 24,999 \ldots \ldots \ldots \ldots \ldots$ & 1.10 & 1.04 & 0.95 & 1.28 & 1.24 & 0.88 & 1.08 \\
\hline$\$ 25,000-\$ 39,999 \ldots \ldots \ldots \ldots . \ldots \ldots$ & 1.08 & 1.01 & 0.95 & 1.19 & 1.12 & 0.83 & 1.16 \\
\hline$\$ 40,000$ or more $\ldots \ldots \ldots \ldots$ & 1.10 & 1.02 & 1.01 & 1.25 & 0.99 & 0.79 & 1.11 \\
\hline \multicolumn{8}{|l|}{ Education of individual } \\
\hline Less than 12 years $\ldots \ldots \ldots \ldots \ldots$ & 1.14 & 1.03 & 0.97 & 1.14 & 1.60 & 0.98 & 1.07 \\
\hline 12 years . . . . . . . . . . . . . . & 1.16 & 1.02 & 0.97 & 1.13 & 1.22 & 0.92 & 1.17 \\
\hline More than 12 years $\ldots \ldots \ldots \ldots$ & 1.10 & 1.03 & 0.98 & 1.23 & 1.09 & 0.82 & 1.28 \\
\hline
\end{tabular}

1The 1977 question asked about 5 or more drinks on any one occasion in the past year, while the 1983 question asked about 5 or more drinks on any 1 day in the past year. 2Desirable weight based on 1960 Metropolitan Life Insurance Company standards. NHIS data are self-reported, and estimates may vary from those that would be obtained if physical measurements were taken.

${ }^{3}$ Based on self-reported identification.

4The income categories for 1983 shown here differ from the 1977 categories shown in Advance Data No. 64. The 1983 income categories contain roughly the same proportion of the 1983

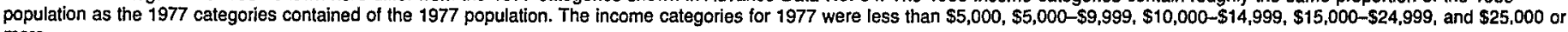
more. 
consumption habits of the American people, but limit the ability to measure changes over time.

Overall, these findings, especially with regard to alcohol use, body weight, and physical activity, suggest the need for further assessment of the progress made toward the 1990 prevention objectives and of the public health education strate- gies designed to accomplish those goals. Progress has been made in the area of smoking reduction, but additional gains are needed to reach the 1990 goal. The recently completed 1985 NHIS Health Promotion and Disease Prevention survey will offer an opportunity to continue to monitor advances toward the national goals. ${ }^{17}$ 


\section{References}

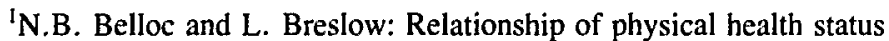
and health practices. Prev. Med. 1(3): 409-421, 1972.

${ }^{2} \mathrm{~J}$.A. Wiley and T.C. Camacho: Life style and future health-evidence from the Alameda County study. Prev. Med. 9: 1-21, 1980.

${ }^{3}$ L. Breslow and J.E. Enstrom: Persistence of health habits and their relationship to mortality. Prev. Med. 9: 469-483, 1980.

${ }^{4}$ Fogarty International Center and American College of Preventive Medicine: Preventive Medicine, U.S.A.-Proceedings of a National Conference on Prevention. New York. Prodist, 1976.

${ }^{5}$ Institute of Medicine: Perspectives on Health Promotion and Disease Prevention in the United States. Washington, D.C. National Academy of Sciences, 1978.

${ }^{6}$ Office of the Assistant Secretary for Health: Disease Prevention and Health Promotion: Federal Programs and Prospects. Report of the Departmental Task Force on Prevention. DHEW Pub. No. (PHS) 79-55071b. Public Health Service. Washington. U.S. Government Printing Office, 1978.

${ }^{7}$ Office of the Assistant Secretary for Health and the Surgeon General: Healthy People: The Surgeon General's Report on Health Promotion and Disease Prevention. DHEW Pub. No. (PHS) 79-55071. Public Health Service. Washington. U.S. Government Printing Office, 1979a.

${ }^{8}$ Office of the Assistant Secretary for Health and the Surgeon General: Healthy People: The Surgeon General's Report on Health Promotion and Disease Prevention-Background Papers. DHEW Pub. No. (PHS) 79-55071a. Public Health Service. Washington. U.S. Government Printing Office, 1979b.

${ }^{9}$ Public Health Service: Promoting Health, Preventing Disease, Objectives for the Nation. DHHS. Washington. U.S. Government Printing Office, 1980.

${ }^{10}$ Office of Disease Prevention and Health Promotion: Promoting health/preventing disease. Public Health Service implementation plans for attaining the objectives for the Nation. Public Health Reports. Supplement to the September/October issue, 1983.

"National Center for Health Statistics, C.A. Schoenborn and K.M. Danchik: Health practices among U.S. adults, United States, 1977.
Advance Data From Vital and Health Statistics. No. 64. DHHS Pub. No. (PHS) 81-1250. Public Health Service. Hyattsville, Md., Nov. 4, 1980.

${ }^{12}$ W.B. Clark and L. Midanik: Alcohol use and alcohol problems among U.S. adults, results of the 1979 national survey, in Alcohol Consumption and Related Problems. Alcohol and Health Monograph. No. 1. National Institute on Alcohol Abuse and Alcoholism. Rockville, Md., 1982.

${ }^{13}$ R.J. Glynn, G.R. Bouchard, J.S. LoCastro, and N.M. Laird: Aging and generational effects on drinking behaviors in men: Results from the Normative Aging Study. Am. J. Public Health 75(12): 1413-1419, 1985.

${ }^{14}$ Metropolitan Life Insurance Company: Overweight, its prevention and significance. Stat. Bull. Metropol. Life Ins. Co. New York. Metropolitan Life Insurance Company, 1960.

${ }^{15}$ National Institutes of Health: Health implications of obesity. $\mathrm{Na}$ tional Institutes of Health Consensus Conference Development Statement. Vol. 5, No. 9, Feb. 11-13, 1985.

${ }^{16} \mathrm{M}$. Rowland and A. White: Personal communication. Hyattsville, Md., 1986.

${ }^{17}$ National Center for Health Statistics: Provisional data from the health promotion and disease prevention supplement to the National Health Interview Survey, United States, January-March 1985. Advance Data From Vital and Health Statistics. No. 113. DHHS Pub. No. (PHS) 86-1250. Public Health Service. Hyattsville, Md., Nov. 15,1985 .

${ }^{18}$ S.G. Haynes, B. Cohen, C. Harvey, and M. McMillen: Cigarette smoking patterns among Mexican-Americans, HHANES, Southwest United States, 1982-84. Paper presented at the 113th Annual Meeting of the American Public Health Association. Washington, D.C., Nov. 1985.

${ }^{19}$ National Center for Health Statistics: Current estimates, 1983. Vital and Health Statistics. Series 10, No. 154. DHHS Pub. No. (PHS) 86-1582. Public Health Service. Washington. U.S. Government Printing Office, 1986. 


\section{Technical notes}

Data presented in this report were obtained from household interviews of the National Health Interview Survey (NHIS). These interviews were conducted among a probability sample of the civilian noninstitutionalized population of the United States. During 1983 approximately 106,000 persons living in about 41,000 households were included in the sample. The total noninterview rate for the NHIS was about 3.3 percent, including 2.0 percent attributable to respondent refusal and 1.3 percent attributable to failure to find an eligible respondent at home after repeated calls.

Questions about health practices were asked of a one-third subsample of all persons 18 years of age and over, or approximately 22,400 persons. This report is based on data for the approximately 21,450 subsample respondents who were 20 years of age and over. Self-reporting was generally required for these questions, but proxy responses were accepted when subsample persons were physically or mentally incapable of answering the questions for themselves. Persons with unknown health practice characteristics are excluded only from the analysis for that particular health practice. Item nonresponse for the data discussed in this report ranged from 0.2 percent for snacking to 3.1 percent for desirable weight.

The measure of desirable weight used in this report was based on the 1960 Metropolitan Life Insurance Company (MLIC) standards of desirable weights for men and women that were derived from the 1959 Build and Blood Pressure Study conducted by the Society of Actuaries. These standards are published in a Metropolitan Life Insurance Company booklet entitled Overweight: Its Prevention and Significance. ${ }^{14}$ Desirable weights were shown for small, medium, and large frames for men and women. For NHIS analyses, the midpoint of the desirable weight range for the medium frame category was used as the "desirable weight" for a particular height, with certain adjustments. The MLIC standards were developed based on weight in indoor clothing and height with 1-inch heels for men and 2-inch heels for women. The NHIS asked respondents to report their height without shoes and their weight without shoes. To compensate for these differences, the MLIC standards were adjusted by subtracting 2 pounds from the midpoint of the medium frame category for both sexes, and subtracting 1 inch from the height for men and 2 inches from the height for women.

Estimates for the white, black, and other populations, shown in table 1 of the text, are based on self-reported racial identifications. The Hispanic classification is also based on self-reporting. For detailed definitions of other sociodemographic terms used here, see appendix II in most Series 10 reports in the Vital and Health Statistics series. In accordance with new Government guidelines, the race and Hispanic origin designations shown in this report differ from those presented in the earlier Advance Data report on health practices of
Standard errors, expressed in percentage points, of estimated percents, NHIS Alcohol and Health Practices Survey, 1983

\begin{tabular}{|c|c|c|c|c|c|}
\hline \multirow{2}{*}{$\begin{array}{l}\text { Base of } \\
\text { percent in } \\
\text { thousands }\end{array}$} & \multicolumn{5}{|c|}{ Estimated percent } \\
\hline & $\begin{array}{c}2 \text { or } \\
98\end{array}$ & $\begin{array}{c}5 \text { or } \\
95\end{array}$ & $\begin{array}{c}10 \text { or } \\
90\end{array}$ & $\begin{array}{c}20 \text { or } \\
80\end{array}$ & 50 \\
\hline$\ldots \ldots \ldots$ & 5.5 & 8.5 & 11.7 & 15.6 & 19.5 \\
\hline$\cdots$ & 4.6 & 7.2 & 9.9 & 13.2 & 16.5 \\
\hline $100 \ldots \ldots$ & 3.9 & 6.0 & 8.3 & 11.0 & 13.8 \\
\hline $300 \ldots \ldots$ & 2.2 & 3.5 & 4.8 & 6.4 & 8.0 \\
\hline$\ldots \ldots$ & 1.7 & 2.7 & 3.7 & 4.9 & 6.2 \\
\hline$\ldots \ldots$ & 1.5 & 2.3 & 3.1 & 4.2 & 5.2 \\
\hline $1,000 \ldots \ldots$ & 1.2 & 1.9 & 2.6 & 3.5 & 4.4 \\
\hline 5,000 & 0.5 & 0.8 & 1.2 & 1.6 & 1.9 \\
\hline 10,000 & 0.4 & 0.6 & 0.8 & 1.1 & 1.4 \\
\hline $20,000 \ldots \ldots$ & 0.3 & 0.4 & 0.6 & 0.8 & 1.0 \\
\hline $30,000 \ldots \ldots$ & 0.2 & 0.3 & 0.5 & 0.6 & 0.8 \\
\hline $50,000 \ldots$ & 0.2 & 0.3 & 0.4 & 0.5 & 0.6 \\
\hline 100,000 & 0.1 & 0.2 & 0.3 & 0.3 & 0.4 \\
\hline
\end{tabular}

the U.S. population. " To calculate the ratios shown in table 8 of this report, the 1977 data were recomputed with race and Hispanic origin designations that resembled, as closely as possible, those shown here for the 1983 population.

Findings presented in this report regarding the smoking practices of Hispanic persons differ somewhat from findings presented elsewhere ${ }^{18}$ for Mexican-Americans living in the Southwest United States, collected in the Hispanic Health and Nutrition Examination Survey (HHANES). HHANES data showed a higher prevalence of current smoking among Mexican-American men and a lower prevalence among MexicanAmerican women than did unpublished sex-specific data from the 1983 NHIS for persons of Hispanic origin. Possible explanations for these discrepancies could include differences in sample design or interviewing procedures, cultural differences between Mexican-Americans and other Hispanic groups (NHIS includes all Hispanic groups), regional differences in smoking behavior, or differences in the age or educational composition of the two Hispanic samples. Analysis of these methodological issues is beyond the scope of this report.

Because the estimates shown in this report are based on a sample of the population rather than on the entire population, they are subject to sampling error. Standard errors appropriate for estimated percents of persons are shown in the table above. The statistics shown and discussed here are simple prevalence estimates, unadjusted for age or other sociodemographic characteristics.

To better understand the limitations of the estimates presented in this report, data users are encouraged to familiarize themselves with the survey design, the methods used in estimation, and the general qualifications of the data, which are described in appendix I of the 1983 Current Estimates report. ${ }^{19}$ Definitions of certain terms used in this report, but not specifically addressed in this section, and the questionnaire and flashcards used during 1983 are presented in appendixes II and III of that report. 


\section{Recent Issues of Advance Data From Vital and Health Statistics}

No. 117. Office Visits to Orthopedic Surgeons, National Ambulatory Medical Care Survey: United States, 1980-81 (In preparation)

No. 116. Aging in the Eighties: Age 65 and Older and Living Alone-Contacts with Family, Friends, and Neighbors: Preliminary Data From the Supplement on Aging to the National Health Interview Survey: United States, January-June 1984 (In preparation)

No. 115. Aging in the Eighties: Preliminary Data From the Supplement on Aging to the National Health Interview Survey: United States, January-June 1984 (In preparation)
No. 114. Prevalence, Impact, and Demography of Known Diabetes in the United States (Issued February 12, 1986)

No. 113. Provisional Data From the Health Promotion and Disease Prevention Supplement to the National Health Interview Survey: United States, January-March 1985

No. 112. 1984 Summary: National Hospital Discharge Survey (Issued Sept. 27, 1985)

\section{Suggested citation}

National Center for Health Statistics, C. A. Schoenborn and B. H. Cohen: Trends in smoking, alcohol consumption, and other health practices among U.S.

adults, 1977 and 1983. Advance Data From Vital and

Health Statistics, No. 118. DHHS Pub. No. (PHS)

86-1250. Public Health Service, Hyattsville, Md., June 30, 1986

\section{Copyright Information}

This report may be reprinted without further permission.

U.S. DEPARTMENT OF HEALTH AND

HUMAN SERVICES

Public Health Service

National Center for Health Statistics

3700 East-West Highway

Hyattsville, Maryland 20782

THIRD CLASS MAIL BULK RATE POSTAGE \& FEES PAID PHS NCHS

PERMIT No. G-281

OFFICIAL BUSINESS

PENALTY FOR PRIVATE USE, $\$ 300$

To receive this publication regularly, contact the National Center for Health Statistics by calling $301 \quad 436-8500$ 